DOI 10.7251/SCMED1802137M

UDC 616.12-009.72-07

COBISS.RS-ID 7839256

\section{Advantages of Percutaneous Coronary Intervention in Relation to Medication Therapy in Patients with Stable Angina Pectoris (Three- Wessel Coronary Disease)}

\begin{abstract}
Patient, a man, age of 66 years, was admitted to the Internal Department, Interventional Cardiology Department for chest pains by type of stable angina pectoris. CCS II. In ambulatory conditions he was made non-invasive diagnostics, and after a positive ergometric test, a decision was made that the patient be admitted to the catheterization hall for invasive diagnosis and possible percutaneous coronary intervention.
\end{abstract}

Key words: angina pectoris, coronary disease, percutaneous coronary intervention, interventional cardiology, case report

(Scr Med 2018:49:137-140)
Nemanja Milićević $\hat{c}^{1}$ Siniša Stojkovićc ${ }^{2}$ Vladimir Miloradović ${ }^{3}$, Siniša Maksimovićc ${ }^{4}$

${ }^{1}$ PHI „Sv Vračevi“ Bijeljina, Internal Department, Department of Interventional Cardiology ${ }^{2}$ Cardiology Clinic, Clinic Center of Serbia

${ }^{3}$ Cardiology Clinic, Clinic Center Kragujevac

${ }^{4}$ PHI „Sv Vračevi“ Bïjeljina

\section{Corresponding author:}

Nemanja Milićević,

e-mail:

nemilo3@gmail.com

Manuscript received: September $11^{\text {th }}, 2018$ Manuscript accepted: November $26^{\text {th }}, 2018$

\section{Introduction}

Three randomized studies compared PCI with medication treatment. The ACME study ${ }^{1,2}$ is planned to evaluate whether PCI is better than optimal pharmacological therapy for alleviating angina in patients with the disease of one and two coronary arteries. PCI previously relieved angina more thoroughly than medicament therapy and was associated with better effort and / or less ischemia in the load test. ${ }^{1}$ Some early beneficial effects of PCI in patients with single-headed coronary disease have been maintained, which makes it an attractive therapeutic option in such patients. ${ }^{2}$ The ACIPO study ${ }^{3}$ is targeted to patients with severe daily ischemia. At the 48-hour Holter ECG, patients had an ischemic effort and at least one episode of silent ischaemia. Two years after randomization, total mortality was significantly reduced, from $6.6 \%$ in the angina-guided strategy to $4.4 \%$ in ischemic strategy and $1.1 \%$ in the revascularization strategy. ${ }^{4}$ (Recommendations for PCI in the treatment of objective extensive ischaemia: IA). However, in patients with no symptoms or with mild symptoms, the situation is different, with poor probability of improvement with PCI, as demonstrated in the AVERT study.,5 After 18 months, $13 \%$ of patients in whom aggressively lowered lipids had episodes of ischemia, in conjunction with $21 \%$ of patients undergoing planned PCI. This difference was initially statistically significant, but it lost significance in a later analysis. There are two major limitations of AVERT experiment: (I) Comparison of pharmacological therapy and PCI is not adequate, as more aggressive hypolipenic therapy is used in the pharmacological part; stenting was done in only $30 \%$, and restenoses that require reintervention are more likely to be in the PCI group than in conservatively treated patients. (II) AVERT did not 
show the anti-ischemic effect of the statin but showed that statins can prevent acute coronary events. RITA-2 was a randomized experiment in which long-term effects of PCI and conservative (pharmacological) treatment of patients with CAD suitable for another therapeutic option were compared.7 After a median follow-up of 2.7 years, in $6.3 \%$ of patients treated with PCI, myocardial infarction or myocardial infarction occurred, as opposed to $3.3 \%$ of patients under medication therapy $(\mathrm{P}=0.02)$. On the other hand, PCI has been associated with greater symptomatic improvement, especially in patients with severe angina. However, RITA-2 can not be applied to today's modern PCI. Only 7.6\% of patients received stents. The study did not mention ticlopidine, clopidogrel, or GP IIb/IIIa inhibitors. The meta-analysis of randomized controlled experiments found that PCI could significantly reduce angina compared to pharmacotherapy, although experiments did not include enough patients for an informative assessment of the effect of PCI on myocardial infarction, death, or later revascularization. ${ }^{8}$ Regardless of involvement in invasive or pharmacological treatment (study TIME) and the administration of at least two antianginos anti-angina drugs, the long-term survival of patients aged 75 or over, in the class of angina II or higher toward the Canadian Cardiac Society (CCS), was similar. Benefits of both types of treatment in relation to angina alleviation and improvement of quality of life were present, but non-fatal events were more frequent in patients under medical therapy. Regardless of whether patients were catheterized at the beginning or only after failing pharmacotherapy, survival was better when they were revascularized in the first year. ${ }^{9}$ Expenses should not be an argument against invasive treatment of elderly patients with chronic angina. ${ }^{10}$

\section{Case Report}

Patient, a man, age of 66 years, was admitted to the Internal Department, Interventional Cardiology Department for chest pains by type of stable angina pectoris. CCS II. In ambulatory conditions he was made non-invasive diagnostics, and after a positive ergometric test, a decision was made that the patient be admitted to the catheterization hall for invasive diagnosis and possible percutaneous coronary intervention. EHO heart: Ao root $35 \mathrm{~mm}, \mathrm{AR}$ 1+, LPK $42 \mathrm{~mm}$, EDD $52 \mathrm{~mm}$, ESD 29 mm, IVS 11 mm, PW 11 mm, EF 60\%, MR 1-2 +.

Ergometry: the physical load test was interrupted in the third minute of grade III due to fatigue and angina pain with the achieved SMF. During the test registered ST depression of $3 \mathrm{~mm}$ in left overdrive and ST elevation in aVR outflow. Earlier it was treated with a mild form of hypertension and hypercholesterolemia. Positive family history.
Finding Coronarography: Right Radial Approach:

LCA: LM: correct deviation, direction, lumen, no stenosis, divides into LAD and LCx. LAD: correct deviation, direction, proximal in the long segment narrowed by tubular stenosis of about $95 \%$, distal stenosis about 50\%. LCx: the correct deviation, direction, gives $\mathrm{OM} 1$ a branchless limb, the $\mathrm{OM} 2$ branch that is proximal narrowed about $60-70 \%$ (tandem lesion) and the $\mathrm{OM}_{3}$ (PD) branch is proximal subcoded to $99 \%$. (Figure 1). RCA: correct deviation, direction, lumen, no stenosis, minor. (Figure 2). (LCA-left coronary artery, LADanterior descending artery, LCx-circumflex artery, OMobtuse marginal artery, PD-posterior descending, RCAright coronary artery.

Figure 1. RAO CAUD (subcooled LAD with stenoses on OM2 and OM3 branches)

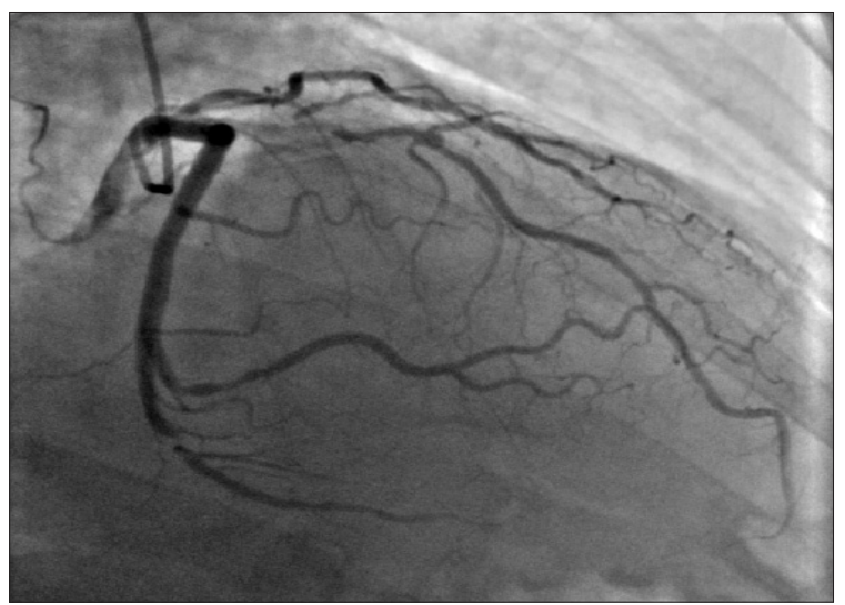

Figure 2. LAO CAUD (Right coronary artery minor)

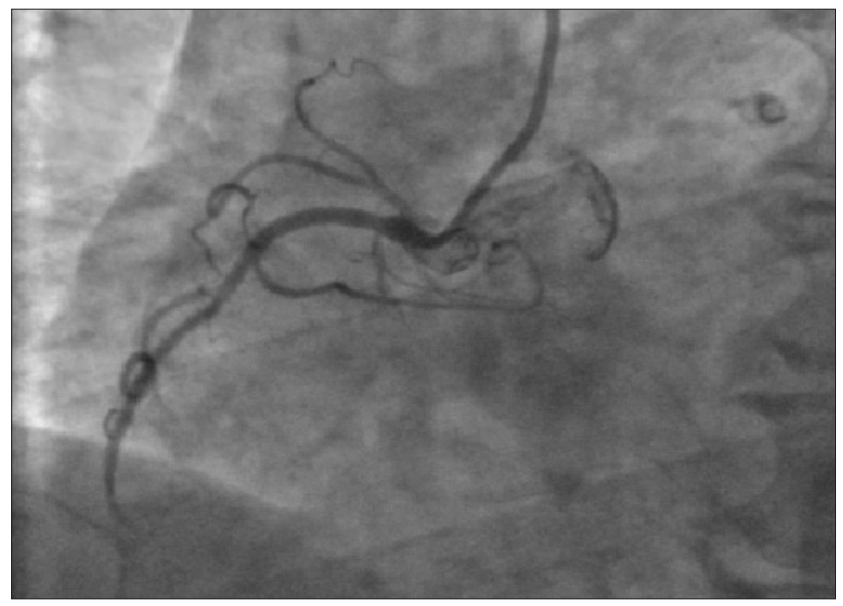

PCI SYNTAX Score II: 23.0; PCI 4 year mortality 3.8\%. CABG SYNTAX Score II: 25,3; CABG 4 year mortality 4.6\%. 
Figure 3. Implanted stent DES Orsiro $3.0 \times 35 \mathrm{~mm}$ and BMS $3,5 \times 15 \mathrm{~mm}$ ower-lap technique with stenoses on OM2 and ОМ3 branches

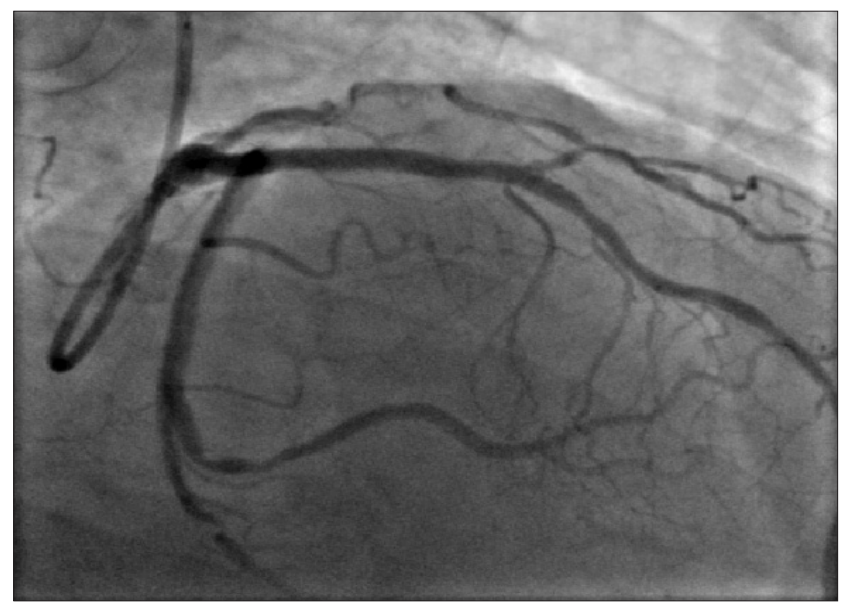

Figure 4. Implanted stents BMS Integrity $2.5 \times 18 \mathrm{~mm}$ in OM3 (PD) branch and stent DES Resolute integrity $2.5 \times 22 \mathrm{~mm}$ in the direction of the OM2 branch

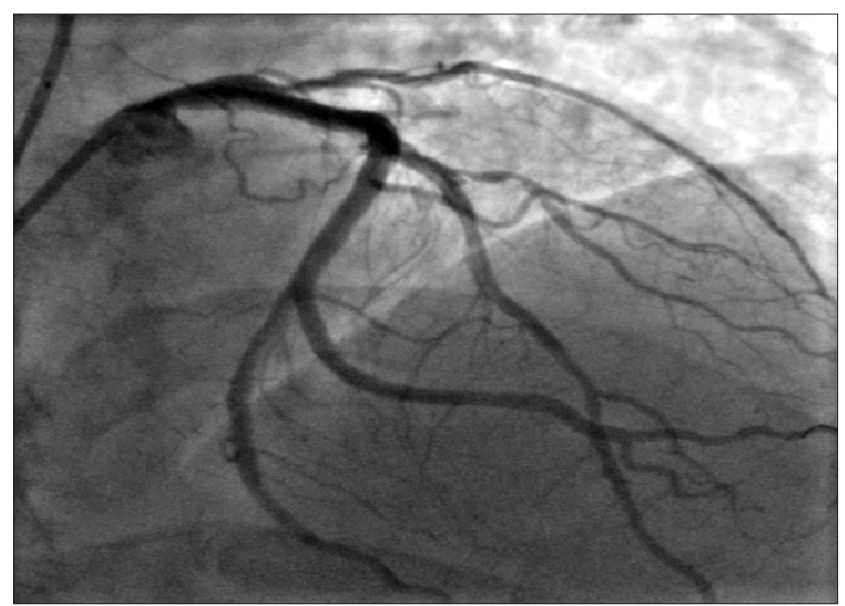

Percutaneous coronary intervention of LAD, OM2 and OM3: given by Heparin a 8000 i.j.i.a. Installed guiding catheter EBU 3.75 from 6 fr to ostium LCA.

PCI LAD: Placed guidwire Runtrough floppy in the direction of $\mathrm{Dg}$ branch as protection and guidwire BMW to the periphery of LAD. Stenosis predilation, SC Pantera balloon 2,0x20mm insufflation to 14atm and balloon NC Sprinter 2,5x15mm insufflation up to 16atm. Implanted stent DES Orsiro $3.0 \times 35 \mathrm{~mm}$ insufflation to 14 atm. Proximally implanted stent ower lap by BMS Integrity $3.5 \times 15 \mathrm{~mm}$ insufflation to $16 \mathrm{~atm}$. After that, POT technique was made, balloon of BMS stent insufflation to $18 \mathrm{~atm}$ and postdilatation of ower lap with insufflation of up to $18 \mathrm{~atm}$. (Figure 3 ).
PCI OM3: Replaced guidwire BMW in PD direction and Direct technique implanted BMS Integrity stent $2,5 \times 18 \mathrm{~mm}$ insufflation to $18 \mathrm{~atm}$.

PCI OM2: Placed guidwire Runtrough floppy in the direction of $\mathrm{OM} 2$ branch and Direct technique implanted stent DES Resolute integrity $2.5 \times 22 \mathrm{~mm}$ insufflation to 16atm. Final result without residual stenosis, without dissection with TIMI flow III. (Figure 4).

\section{Conclusion}

The patient was admitted to the catheterization hall due to chest pains by the type of stable angina pectoris with a positive physical fatigue test. After percutaneous coronary intervention, the patient was discharged to a home without symptoms and electrocardiographic signs of ischemia with a proposal to continue treatment with medication (dual antiaggregation therapy and high dose statins). At the checkup, after a month and six months, the patient still has no problems with the proposal to continue the prescribed therapy for one year. The aim of the case is to indicate the significance of percutaneous coronary intervention in patients with stable angina pectoris versus drug therapy. The procedure must be gradual and carefully planned. Conclusion based on the literature and the case itself, a patient with a clinical picture has stable angina pectoris and well-performed non-invasive diagnostics, they discover with significant coronary artery stenosis. Consequently, the performance of PCIs in such patients can be considered as a more effective treatment method than a medical treatment due to a reduction in the symptoms itself and the development of consequent ischemic cardiac insufficiency.

\section{References}

1. Parisi AF, Folland ED, Hartigan P. A comparison of angioplasty with medical therapy in the treatment of single-vessel coronary artery disease. Veterans Affairs ACME Investigators. N Engl J Med 1992;326:10-6.

2. Hartigan PM, Giacomini JC, Folland ED, Parisi AF. Two- to three-year follow-up of patients with single-vessel coronary artery disease randomized to PTCA or medical therapy (results of a VA cooperative study). Veterans Affairs Cooperative Studies Program ACME Investigators. Angioplasty Compared to Medicine. Am J Cardiol 1998;82:1445-50.

3. Pepine CJ, Geller NL, Knatterud GL, Bourassa MG, Chaitman BR, Davies RF, Day P, Deanfield JE, Goldberg AD, McMahon RP. The Asymptomatic Cardiac Ischemia Pilot (ACIP) study: design of a randomized clinical trial, baseline data and implications for a long-term outcome trial. J Am Coll Cardiol 1994;24:1-10.

4. Davies RF, Goldberg AD, Forman S, Pepine CJ, Knatterud GL, Geller N, Sopko G, Pratt C, Deanfield J, Conti CR. Asymptomatic Cardiac Ischemia Pilot (ACIP) study two- 
year follow-up: outcomes of patients randomized to initial strategies of medical therapy versus revascularization. Circulation 1997;95:2037-43.

5. Pitt B, Waters D, Brown WV, van Boven AJ, Schwartz L, Title LM, Eisenberg D, Shurzinske L, McCormick LS. Aggressive lipid-lowering therapy compared with angioplasty in stable coronary artery disease. Atorvastatin versus Revascularization Treatment Investigators. N Engl J Med 1999;341:70-6.

6. Amoroso G, Van Boven AJ, Crijns HJ. Drug therapy or coronary angioplasty for the treatment of coronary artery disease: new insights. Am Heart J 2001;141:S22-S25.

7. The RITA-2 trial participants. Coronary angioplasty versus medical therapy for angina: the second Randomised Intervention Treatment of Angina (RITA-2) trial. RITA-2 trial participants. Lancet 1997;350:461-8.

8. Bucher HC, Hengstler P, Schindler C, Guyatt GH. Percutaneous transluminal coronary angioplasty versus medical treatment for non-acute coronary heart disease: meta-analysis of randomised controlled trials. BMJ 2000;321:73-7.

9. Pfisterer M. Long-term outcome in elderly patients with chronic angina managed invasively versus by optimized medical therapy: four-year follow-up of the randomized Trial of Invasive versus Medical therapy in Elderly patients (TIME). Circulation 2004; 110:1213-18.

10. Claude J, Schindler C, Kuster GM, Schwenkglenks M, Szucs T, Buser P, Osswald S, Kaiser C, Grädel C, Estlinbaum W, Rickenbacher P, Pfisterer M. Cost-effectiveness of invasive versus medical management of elderly patients with chronic symptomatic coronary artery disease. Findings of the randomized trial of invasive versus medical therapy in elderly patients with chronic angina (TIME). Eur Heart $\mathrm{J}$ 2004;25:2195-203.

\section{Prednosti perkutane koronarne intervencije u odnosu na medikamentoznu terapiju kod pacijenata sa stabilnom anginom pektoris (trosudovna koronarna bolest)}

\section{SAŽETAK}

Uvod: Cilj ovog rada je prikazati postupak perkutane koronarne intervencije kod pacijenata sa stabilnom anginom pektoris i njene prednosti, s obzirom da se ne preporučuje rutinska $\mathrm{PCl}$ kod pacijenata sa stabilnom anginom prema važećim preporukama, dobijenih na osnovu velikih radomizovanih studija, koje će kroz rad biti opisane.

Prikaz slučaja: U Pacijent, muškarac, životne dobi od 66 godina, primljen je na Interno odelenje, odsek za Interventnu kardiologiju zbog bolova u grudima po tipu stabilne angine pektoris. CCS II. U ambulantnim uslovima mu je učinjena neinzvazivna dijagnostika, te nakon pozitivnog ergometrijskog testa, donešena je odluka da se uradi invazivna dijagnostika i eventualna PCl. PCI SYNTAX Score II: 23,0; PCI četvorogodišnji mortalitet 3,8\%. CABG SYNTAX Score II: 25,3; CABG četvorogodišnji mortalitet 4,6\%. Koronarografija: LCA: LM: pravilnog odstupa, pravca, lumena, bez stenoza, račva se na LAD i LCx. LAD: pravilnog odstupa, pravca, proksimalno u dužem segmentu sužena tubularnom stenozom oko 95\%, distalno stenoza oko 50\%. LCx: pravilnog odstupa, pravca, daje OM1 granu koja je bez suženja, OM2 granu koja je proksimalno sužena oko 60-70\% (tandem lezija) i OM3 (PD) grana je proksimalno subokludirana 99\%. RCA: bez stenoza, minorna. PCI LAD: Implantiran stent DES Orsiro $3,0 \times 35 \mathrm{~mm}$ insuflacijom do $14 \mathrm{~atm}$. Proksimalno implantiran stent ower lap tehnikom BMS Integrity $3,5 \times 15 \mathrm{~mm}$ insuflacijom do 16atm. Nakon toga, urađen POT tehnika, balonom od BMS stenta insuflacijom do 18atm i postdilatacija ower lap-a insuflacijom do 18atm. PCI OM3: Replasiran guidwire BMW u pravcu PD grane i Direct tehnikom implantiran stent BMS Integrity 2,5x18mm insuflacijom do 18atm. PCI OM2: Plasiran guidwire Runtrough floppy u pravcu OM2 grane i Direct tehnikom implaniran stent DES Resolute integrity 2,5x22mm insuflacijom do 16atm. (LCA-leva koronarna arterija, LAD-prednja descendentna arterija, LCx-cirkumfleksna arterija, OM- optuzna marginalna arterija, PD- zadnja descedentna arterija, RCA-desna koronarna arterija).

Zaključak: Procedura mora biti postupna, pažljivo planirana i da tek nakon inicijalne i dobre neinvazivne dijagnostike, se treba pristupiti odluci o perkutanoj koronarnoj intervenciji. Značajan stepen stenoza na koronarnim arterijama i tegobe koje pacijent ima su presudne u odluci o izvođenju PCl. Ako se pažljivo izvodi, PCl se i dalje može smatrati dragocenom tehnikom kod odabranih pacijenata u odnosu na samu medikamentoznu terapiju.

Ključne riječi: angina pektoris stabilis, perkutana koronarna intervencija, medikamentozna terapija 